\title{
The Comparative Analysis of Altman Z-Score, Springate, Zmijewski, And Internal Growth Rate Model in Predicting the Financial Distress (Empirical Study on Mining Companies Listed on Indonesia Stock Exchange 2014-2017)
}

\author{
Sri Mulyati \\ Management Program, Faculty of Economics, Universitas Islam \\ Indonesia \\ Syahrul Ilyasa \\ Management Program, Faculty of Economics, Universitas Islam \\ Indonesia \\ mulyati@uii.ac.id
}

\begin{abstract}
This study aims to: (1) determine whether there are differences in scores between the Altman model, Springate, Zmijewski and Internal Growth Rate in predicting financial distress, (2) find out the most accurate prediction model in predicting financial distress of mining companies in Indonesia. The data used in this study is the company's financial statements published on Indonesia Stock Exchange. The population in this study is the mining companies listed on the Indonesia Stock Exchange during 2014-2017 which are 41 issuers. The sampling technique used purposive sampling so that 36 issuers were obtained as the research samples. This study compares the scores of four financial distress prediction models using statistical techniques and the accuracy of the prediction model by considering the level of accuracy and type I error. The conclusions from this study indicate the differences between the four prediction models. The Springate model is the best with an accuracy rate of $88.89 \%$ and an $8 \%$ type I error, the second is the Zmijewski model with an accuracy rate of $88.89 \%$ and a type I error rate of $42.86 \%$, the third is the Altman model with $75 \%$ accuracy and error type I $46.67 \%$, and the last is an internal growth rate model with an accuracy rate of $66.69 \%$ and type I error rate of $11.11 \%$.

Keywords: financial distress, financial statements, mining, prediction models
\end{abstract}

JEL : : G32

DOI : 10.24002/kinerja.v22i2.3231

Received : 11/26/2019 Reviewed: 01/29/2019 Final Version: 02/20/2020 
The Comparative Analysis of Altman Z-Score, Springate, Zmijewski, And Internal Growth Rate Model in Predicting the Financial Distress (Empirical Study on Mining Companies Listed on Indonesia Stock Exchange 2014-2017)

(Sri Mulyati and Syahrul Ilyasa)

\section{INTRODUCTION}

Rapid business competition demands companies to continue developing innovations, improving their performance and expanding their businesses in order to continue to survive and compete. The company's ability to compete is determined by the company's performance itself. The company that is unable to compete in maintaining its performance will gradually be displaced from their industrial environment and will experience financial distress which will lead to bankruptcy. Bankruptcy is a condition where the company is no longer able to operate the company properly due to financial distress or financial distress experienced by the entity is already severe. In order to maintain the survival of the company, the management must improve its performance. According to Dermawan Sjahrijal (2008: 202) financial distress is a condition in which a company experiences financial distress and is threatened with bankruptcy. If the company goes bankrupt, there will be bankruptcy costs caused by the cost of being forced to sell the assets below the market price, the company's liquidity costs, the impairment of fixed assets that is expired before sold and others.

Mining is one of the sectors listed on the Indonesia Stock Exchange. According to the Indonesia Stock Exchange data (2018), the mining sector has four subsectors with a total of 41 registered issuers. In 2018, the performance of mining issuers especially the coal sub-sector continues to increase along with the high demand for this energy commodity. However, the increasing shares were not all evenly distributed. The mining sectors with the lowest shares were PT Bumi Resources Tbk (BUMI) which shares price dropped $-15.56 \%$ year-to-dates, PT SMR Utama Tbk (SMRU) by $-7.05 \%$, PT Adaro Energy Tbk (ADRO) of $-3.23 \%$. In 2017, there were two mining companies that were delisting from the Indonesia Stock Exchange, namely Berau Coal Energy Tbk. (BRAU) and Permata Prima Sakti Tbk. (TKGA). Some cases of delisting are caused by the company's inability to pay debts and experiencing financial distress. It is similar to BRAU which was formerly named PT Risco that was going public in the Indonesia Stock Exchange on August 19, 2010. At that time, the company sold 3.4 billion shares with Rp 400 per share as the offer price. In April 2012, BRAU shares had touched the highest level in history which was at the level of Rp. 540 per share. Although in the past years BRAU's net profit continued to decline, in 2010 BRAU's net was cut $27.39 \%$ to $\mathrm{Rp} 619.8$ billion due to rising sales expenses which reached $\mathrm{Rp} 6.23$ trillion. BRAU's performance has continued to decline since 2013. Moreover, in July 2015, the company was known to have failed to pay debt of US \$ 450 million which was due at that time. At the time of delisting, BRAU shares had already collapsed at the level of Rp 82 per share.

One method to measure the company's financial performance is done by analysing the financial statements reported by the company on each period. The financial distress model needs to be developed because by recognizing the financial distress early, some actions can be done to anticipate the conditions that lead to bankruptcy. There are many methods to predict a company's financial 
distress. However, in this study, there are four models chosen including Altman ZScore, Springate, Zmijewski, and Internal Growth Rate. This study aims to determine whether there are differences in the scores of each model, and find out which model has the highest level of accuracy in predicting financial distress in mining sector companies listed on the Indonesia Stock Exchange.

\section{LITERATURE REVIEW}

\subsection{Company Financial Performance}

Financial performance is a description of a company's financial condition that reflects on the merits of a company's work performance in a certain period. It is very important to know so that resources can be used optimally in facing rapid environmental changes. Financial performance research includes research on the past financial situation with objectives that have been determined through certain analysis. The company's financial performance is the company's assessment of the financial position and ability to manage existing resources where information resources, financial structure, liquidity, solvency, profitability, activities and ability to adapt to environmental changes are needed to predict the company's ability to meet its financial commitments so that from these predictions can it is known, whether the company's financial performance is good or not good.

Based on the understanding of company performance, the benefits of company performance evaluation are as follows:

1. to find out the achievements of a company during a certain period whether it is good or not, efficient or unhealthy or not as a whole.

2. to be used for assessing the organization as a whole and can also be used to assess the contribution of a part in achieving overall company goals.

3. as materials in making decisions and organizational activities in general and divisions in particular and as a basis for investment policies in order to improve company efficiency and productivity.

\subsection{Financial Distress Understanding}

There are several opinions about financial distress that equate financial distress with bankruptcy. However, basically this is different. Financial distress is one of the causes of bankruptcy in terms of corporate finance while there are still many factors outside of finance that can cause company bankruptcy. Every company that experiences financial distress will not always go bankrupt, depending on the management whether they can overcome this problem or not because basically financial distress is a signal of bankruptcy of a company.

It can be said that as long as the company's cash flow is greater than its debt obligations, the company will have enough funds to pay its creditors. The key factor in identifying whether a company is in financial distress is a condition in 
which the company experiences negative net operating income for several years and it has not made dividend payments, terminated employment or eliminated dividend payments for more than one year (Almilia and Kristijadi, 2003).

Financial distress begins when the company cannot meet the payment deadline or when the cash flow projection indicates that the company will soon be unable to meet its obligations (Brigham and Daves, 2003). There are several definitions of financial distress, according to their type are such as economic failure, business failure, technical insolvency, insolvency in bankruptcy, and legal bankruptcy (Brigham and Gapenski, 1997).

\subsection{Indicators of Financial Distress and Bankruptcy}

According to Harnanto (2007), before a company was finally declared bankrupt, it is usually marked by various situations or circumstances specifically related to the effectiveness and efficiency of its operations. The indicators that must be considered by managers, as stated are:

1. the decreasing of sales volume due to changes in consumer tastes or demands

2. the increasing of production costs

3. the increasing levels of competition

4. the failure to expand

5. the ineffectiveness in carrying out the function of collecting receivables

6. the lack of support or banking facilities (credit)

7. the high level of dependence on receivables.

\subsection{The causes of Financial Distress and Bankruptcy}

Munawir (2002: 289) explains that the causes of financial distress that lead to bankruptcy basically can be caused by internal and external factors of the company, either those that are specifically related directly to the company or those that are general.

Internal factors can be caused by the bad and inefficient (large costs with inadequate income so that the company suffers continuous losses) management. Inefficient management may be caused by lack of management capabilities, experiences and skills. Besides that, there is an imbalance between the amounts of company capital with the amount of debt. Debts that are too big can result in high interest costs and be a burden for the companies. However, too many receivables can also harm the company because too large working capital embedded in accounts receivable will result in reduced company liquidity. In addition, the overall lack of adequate skills, integrity and loyalty or even low morality can cause many mistakes, irregularities and frauds against the company's finances and abuse of authority which will consequently be very detrimental to the company. 
General external factors that can cause financial distress that lead to bankruptcy of a company are political, economic, social, and cultural factors as well as the level of government interference in which the company is located. In addition, the wrong use of technology can also result in implementation costs and maintenance costs incurred to be large so that it can cause companies to go bankrupt. External factors that are specific, meaning other factors directly related to the company, including customers, suppliers and competitors. The company must establish a good relationship with suppliers so that suppliers do not act at their own pace in rising prices that can be detrimental to the company. In addition, companies should not ignore large competitors and small competitors.

\subsection{Benefits of Predicting Financial Distress}

One of the company's responsibilities is to produce good performance to avoid financial distress. This performance can be reflected in its ability to predict the aforementioned indicators. These predictions can provide benefits to the company (Foster, 1986) such as:

1. Creditor Close relationships with institutions, whether to make a decision to provide loans under certain conditions or design policies to monitor existing loans.

2. Investor

Distress prediction model could help investors in determining attitudes towards securities issued by a company. Investors can develop a strategy based on the assumption that the financial distress prediction model can be an early warning of financial distress in a company.

3. Regulatory Affairs Authority

Similar to the accountant association, capital market supervisor, or other institutions, the studies about financial distress are helpful to issue policies for protecting the society.

4. Government

The government has an obligation to protect the workforce, industry and society. This could help in issuing regulations to protect the public from loss and the possibility to disrupt the country's economic and political stability.

5. Auditor

A study that must be made by the auditor is whether the company can be going concern or not. With the existence of a model to predict bankruptcy, the auditor can audit and give an opinion on the company's financial statements better.

6. Management

Financial Distress will cause costs both directly and indirectly. Direct costs include wage costs for accountants and lawyers. While indirect costs is lost sales or profits due to restriction imposed by the court. To avoid such substantial costs, management with indicators of financial distress can make preparations to anticipate the worst. 


\subsection{Altman Distress Prediction Model (Z-Score)}

This analysis has been used since the 1970s and became famous in the 1980s. The analytical model developed by Altman has become a reference for every investor and investment manager in the United States in the process of examining their investment decisions to avoid the possibility of investment mistakes in companies that are predicted to experience financial distress. After conducting research on selected variables and samples, there are three kinds of discriminant functions of the Altman Z-Score model. These three models have differences in the objects that Altman examines. In addition, these three models have different formulas and cut-offs. The first model is the Original Z-Score (for public manufacturers) which is the first z-score discriminant function developed by Altman. This model was developed in 1968 which was aimed at public manufacturing companies. The second model is the A Z-Score model (for private manufacturer). This model was developed by Altman in 1983 for a private manufacturer company. And the third model is the model that is used in this study, namely the B-Z Score Model (for non manufacturing firms). This model was developed by Altman in 1983 in conjunction with the development of the A Z-score model. Altman developed this model to predict bankruptcy in non-manufacturing companies such as small businesses, mining and the service sector. In this B-Z model, the $X 5$ value or the value of sales to total assets is not calculated because it always changes significantly in the industry. The equation from the third model is:

$$
Z=6,56 \times 1+3,26 \times 2+6,72 \times 3+1,05 \times 4
$$

(Source: Altman, 1983)

Notes:

$\mathrm{Z}=$ distress and bankruptcy index

$\mathrm{X} 1=$ working capital / total assets

$\mathrm{X} 2$ = retained earnings $/$ total assets

$\mathrm{X} 3=$ earnings before interest and taxes/total assets

$\mathrm{X} 4$ = market value of equity / book value of total debt

$Z$ score is the overall index of the multiple discriminant analysis function. According to Altman, there are cut offs of $Z$ score that can determine whether the company will be in financial distress in the future that are divided into three categories, namely:

1. If $Z<1.10$, the company belongs to unhealthy company and potentially being in financial distress in the future.

2. If $\mathbf{1 . 1 0} \leq Z \leq \mathbf{2 . 6 0}$, the company belongs to grey area (cannot be decided whether it belings to healthy company or the one that is in financial distress).

3. If nilai $Z>2.60$, the company is healthy and not potentially being in financial distress. 


\subsection{Distress Prediction Model Springate (S-Score)}

According to Peter \& Yoseph (2011), Springate model is a financial distress prediction model that is based on the study done by G. I. V. Springate in 1978 that is known as Springate model or Canadian model. The study done by Springate in 1978 was based on the procedure modeled by Altman using Stepwise Multiple Discriminant Analysis to choose four out of nineteen popular financial ratios to differentiate between healthy company and the bankrupt one. The formula used in Springate model is as follows:

\section{$S=1.03 A+3.07 B+0.66 C+0.4 D$}

(source: Springate, 1978)

in which:

A $=$ Working Capital / Total Assets

$B=$ Net Profit before Interest and Tax $/$ Total Assets

$C=$ Net Profit before Tax / Current Liability

$\mathrm{D}=$ Sales $/$ Total Assets

The critical value standard determined by Springate is if S-score $>0,862$, the company belongs to the healthy company. Meanwhile, if the S-score $\leq 0,862$, the company is considered as having low soundness and potentially having financial distress in the future.

\subsection{Distress Prediction Model Zmijewski (X-Score)}

Zmijewski (1984) gives one crucial matter as a condition in which the proportion from the sample and population should be determined in the beginning to get the frequency unit of the financial distress. This frequency is obtained by dividing the total samples that have financial distress with the whole samples (Rismawati, 2012). Zmijewski model was once used in the study done to the 40 bankrupt company and 800 non- bankrupt companies. The accuracy level of this model in estimating the samples is 99\% (Avenhuis, 2013). The bankruptcy prediction in Zmijewski model uses three financial ratios, namely (Zmijewski, 1984):

1. ROA (Return on Asset)

This ratio portrays the ability of the company in changing the assets owned into a benefit that may increase the total asset totally. The bigger ratio shows the better company soundness.

$\mathbf{R O A}=\frac{\text { EAT }}{\text { Total Assets }}$ 
2. Debt Ratio

This ratio shows the ability of the company in paying off the debt using the assets owned. The higher the ratio shows the worse company soundness.

DR $=\frac{\text { Total Liabilities }}{\text { Total Assets }}$

3. Current Ratio

This ratio indicates the ability of the company to compensate the liabilities using the total assets. The higher the ratio shows the better the company soundness.

CR $=\frac{\text { current assets }}{\text { current liabilities }}$

On the Zmijewski model analysis, financial distress is predicted using this formula:

in which:

$$
\mathrm{X} \text {-Score }=-4,3-4,5 \mathrm{X} 1+5,7 \mathrm{X} 2-0,004 \mathrm{X} 3
$$

(source: Zmijewski, 1984)

$\mathrm{X} 1=\mathrm{EAT} / \mathrm{Total}$ Assets

X2 = Total Liabilities/Total Assets

X3 = Current assets/ current liabilities

Cut-off used in this model is 0 that potentially being in a financial ditress in the future. If the $\mathrm{X}$-Score is negative or below than 0 , the company is considered as healthy.

\subsection{Distress Prediction Model Internal Growth Rate (IGR-Score)}

Ross (2009) defines Internal Growth Rate as maximum growth rate a firm can achieve without external financing of any kind or the maximum growth level achieved by the company without using external funding. The formula used in Internal Growth Rate model is as follow:

IGR $=\frac{\text { Return on Asset x b }}{1-(\text { Return on Asset x b })}$

According to Ross (2009), ROA (Return on Asset) is a measurement unit which is for a unit of profit for each currency of the assets formulated as follows:

ROA $=\frac{\text { Net Income }}{\text { Total Asset }}$

In the formula of Internal Growth Rate, $b$ is Retention Ratio that is an additional retained earning divided by the net income and then called as Plowback Ratio 
(Ross, 2009). Retention Ratio can also be defined as profit or income Reinvestment Rate. The formula for Retention Ratio is as follows:

$$
\mathbf{b}=\frac{\text { Net Income }- \text { Deviden }}{\text { Net Income }}
$$

The use of Internal Growth Rate as the bankruptcy prediction was analyzed first time by Fony (2003). In his study, the population is 129 private banks registered in 1999 and the samples are 86 national private banks consisting of 29 bankrupt banks (being liquidated in 1999) and 57 non- bankrupt banks. The data analysis technique is using SPSS program version 10 about multivariate analysis and the discriminant analysis is done using step-wise estimation methods. The accuracy level of prediction from this model is $60.5 \%$. This study results into a formula for bankruptcy prediction:

\section{IGR Score = -1.514 + 165.6681IGR}

(source: Ross, 2009)

in which:

IGR Score = the bankruptcy prediction score

IGR = Internal Growth Rate

If a company has IGR Score $>0.238$, the company is classified into unhealthy company. Meanwhile, if the IGR Scores is below than -0.477 , the company is classified into healthy company. While, if $-0.477 \geq 1 \mathrm{GR}$ Score $\geq 0.238$, it cannot be decided whether the company is healthy or in financial distress.

\section{METHODOLOGY}

\subsection{Sampling Technique}

In this study, the population is all mining companies listed in Indonesia Stock Exchange. This study used a purposive sampling. It is a sampling method that uses specific consideration (Sugiyono, 2005:78). This technique aims to get representative samples that match to the consideration and criteria determined. The criteria are as follows:

1. The mining companies that are listed in Indonesia Stock Exchange from 2014 to 2017 in a row.

2. The companies issuing annual report completely from 2014 to 2017.

3. The companies which the cut off of the financial report is on 31 December.

Based on the criteria mentioned before, there were 36 mining companies chosen as the samples. 


\subsection{Data Analysis Technique}

The data analysis techniques used is the accuracy of prediction model that is used to measure the level of accuracy of companies that are in financial distress and the ones that are not in financial distress on each technique. Then, the prediction and the actual condition of the sample in 2017 were compared. The formula to obtain the prediction is as follows:

$$
\text { Prediction result }=\frac{\text { Score } 2014+2015+2016}{3}
$$

The prediction result was compared to the score of the company's actual condition in 2017. The level of accuracy shows how big the percentage of the model is in predicting corectly from all existing samples. The level of accuracy of each model is obtained using this formula:

$$
\text { Level of accuracy }=\frac{\text { total of correct predictions }}{\text { total samples }} x 100 \%
$$

Besides the accuracy level of each model, another consideration is the level of errors. The researcher divided errors into two types namely Type I and Type II. Type I error is an error that happens if the model wrongly predicts that a company is in a financial distress whereas in fact it is not. The level of error is formulated below:

$$
\begin{aligned}
& \text { Type I Error } \\
& =\frac{\text { Total error type I error }}{\text { Total of Sample Distress }} \times 100 \% \\
& \text { Type II Error } \\
& =\frac{\text { Total type II error }}{\text { Total of Sample Distress }} x 100 \%
\end{aligned}
$$

The best model is the one that has the highest level of accuracy and has a low score for the type I error.

\section{RESULT AND DISCUSSION}

\subsection{Altman Z-score Model}

Altman Z-score model can predict accurately 27 out of 36 samples. It means that the level of accuracy is $75 \%$. The nine out of 36 samples were predicted inaccurately. The level of error for this model is $25 \%$ consisting two error types namely type I error and type II error. 
Eight out of 15 companies were accurately predicted in distress. Thus, the type I Error is $46.67 \%$. Meanwhile, they were 19 out of 21 that were predicted accurately in the non-financial distress and grey area. Two samples were predicted wrongly so the Type II Error is $9.52 \%$.

\subsection{Springate Model}

Springate model can predict 32 out of 36 sample accurately in $88.89 \%$ as the level of accuracy, meaning that four out of 32 samples were wrongly predicted Thus, the level of error of this model is $11.11 \%$ varied in type I error dan type II error. Meanwhile, there were 23 out of 25 samples that were predicted accurately in distress. The two samples that are wrongly predicted indicates that the type I error is $8.00 \%$. Then, nine out of eleven samples were predicted accurately as being in non-financial distress. Therefore, the type II Error is $18.18 \%$.

\subsection{Zmijewski Model}

Zmijewski model can predict 32 out of 36 samples accurately which means that the level of accuracy is $88.89 \%$. As four samples were predicted wrongly, the level of error is $11.11 \%$ consisting in 2 error types namely type I error dan type II error. Then, four out of seven samples were predicted accurately that they were in distress. It shows that the type I Error is $42.86 \%$ as there are three samples that were predicted wrongly. It was also obtained that there were 28 out of 29 companies that were predicted accurately as being in non-financial distress. Therefore, the type II Error is counted into 3.45\%.

\subsection{Internal Growth Rate Model}

Internal Growth Rate model could predict 24 out of 36 samples accurately. Thus, the level of accuracy is $66.67 \%$. As there were 12 out of 26 samples that were wrongly predicted, it refers that the level of error is $33.33 \%$ vairied in type I error and type II error. There were eight out of nine samples that were predicted accurately as being in financial distress. One sample that was predicted wrongly means that the type I Error is $11.11 \%$. Furthermore, there were 16 out of 27 companies that were predicted accurately in non-distress. 11 samples were inaccurately predicted indicates that there is a type II Error in $40.47 \%$.

\subsection{The Comparison between Altman, Springate, Zmijewski and Internal Growth Rate Model}

Here are the tables and the explanation for evaluating the level of accuracy, type I error and type II error of the four models:

Table 1 The Comparison between Accuracy and Error obtained from Prediction Models

\begin{tabular}{|c|c|c|c|}
\hline Model & Level of Accuracy & Type I error & Type I error \\
\hline Springate & $88.89 \%$ & $8.00 \%$ & $11.18 \%$ \\
\hline
\end{tabular}


The Comparative Analysis of Altman Z-Score, Springate, Zmijewski, And Internal Growth Rate Model in Predicting the Financial Distress (Empirical Study on Mining Companies Listed on Indonesia Stock Exchange 2014-2017)

(Sri Mulyati and Syahrul llyasa)

\begin{tabular}{|c|c|c|c|}
\hline Zmijewski & $88.89 \%$ & $42.86 \%$ & $3.45 \%$ \\
\hline Altman Z- Score & $75.00 \%$ & $46.67 \%$ & $9.52 \%$ \\
\hline Internal Growth Rate & $66.67 \%$ & $11.11 \%$ & $40.47 \%$ \\
\hline
\end{tabular}

Source: calculated by the researcher

The table above shows that level of accuracy of Springate model is as high as Zmijewski model in predicting companies that were in financial distress and nondistress in mining sector from 2014 up to 2017 which is $88.89 \%$. Meanwhile, Altman Z score model has lower level of accuracy which is $75 \%$ and the lowest one was resulted from the internal growth rate model which is $66.67 \%$.

Seen from type I Error, Springate model has the lowest level of error in $8 \%$ compared to Zmijewski which is in $42.86 \%$ and internal growth rate in $11.11 \%$ and Altman counted in $46.67 \%$. It infers that although both models have the same level of accuracy, Springate model tends to have lower level of error in predicting companies that are in financial distress. In the context of type II Error, Zmijewski model was in the lowest position in $3.45 \%$, followed by Altman in $9.52 \%$, Springate in $18.18 \%$ and highest error level was in internal growth rate which is in $40.47 \%$. It shows that Zmijewski model has the lowest error level in predicting whether companies are healthy or being in non-financial distress. Based on the level of accuracy and type II error, Springate model is the best followed by Zmijewski model, Altman model, and internal growth rate model is the last.

\section{CONCLUSION}

Aiming at investigating whether there are difference scores dealing with level of accuracy resulted from Altman Z-Score, Springate, Zmijewski and Interal Growth Rate model in predicting the financial distress and determining the most accurate prediction model in predicting financial distress of mining companies listed in Indonesia Stock Exchange from 2014 up to 2017, this study results in some conclusions. There is different score in accuracy level predicted by Altman ZScore, Springate, Zmijewski and Internal Growth Rate model dealing with predicting Financial Distress. These differences can be seen from the level of accuracy obtained from the prediction models and its level of error. In this study, it was found that Springate model has accuracy level within $88.89 \%$, the error type I was in $8 \%$ and error type II was in $18.18 \%$. It is almost the same as Zmijewski model that has level of accuracy in $88.89 \%$, error type I in $42.86 \%$ and error type II in $3.45 \%$. Altman model has level of accuracy in $75 \%$ error type I in $46,67 \%$ and error type II in 9.52\%. Meanwhile, internal growth rate model has the level of accuracy in $66.67 \%$ error type II in $11.11 \%$ and error type II in $40.47 \%$. Overal, it can be seen that Springate and Zmijewksi models have the same level of accuracy. Yet, Springate model tends to have lower error type I. Considering the level of accuracy and type I error, the best prediction model is Springate model, followed by Zmijewski model, Altman model, and internal growth rate as the last. 
There are some suggestions notified by the researcher to have better future research. There should be an addition prediction model so there are four models used such as Grover, Fulmer, Zavgren or other prediction models. This kind of study should be applied in construction, banking and other sectors.

\section{REFERENCES}

Almilia, L.S. and Kristijadi, E. 2003. Analisis Rasio Keuangan untuk Memprediksi Kondisi Financial Distress Perusahaan Manufaktur yang Terdaftar Di Bursa Efek Jakarta. Jurnal Akuntansi dan Auditing Indonesia (JAAI), vol 7, number 2, p 1-27.

Altman, E. I. 1968. Financial Ratios, Discriminant Analysis and The Prediction of Corporate Bankruptcy. The Journal of Finance. vol. 23, number 4, p. 589-609.

Altman, E. I. 2000. Predicting Financial Distress of companies: Revisiting the $Z$ Score and Zeta ${ }^{\circledR}$ Models. Updated from E. Altman, Financial Ratios, Discriminant. Analysis and the Prediction of Corporate Bankruptcy, Journal of Banking \& Finance, 1.

Avenhuis, J.O., 2013. Testing The Generalizability of The Bankruptcy Prediction Models of Altman, Ohlsonand Zmijewski for Dutch Listed And Large NonListed Firms, Journal of Business Administration, Publisher: University of Twente, 38-39.

Brigham, E.F., \& Daves, P.R., 2003. Intermediate Financial Management with Thomson One. United States of America: Cengage South-Western.

Brigham, E.F., \& Gapenski L.C. 1997. Financial Management-Theory and Practice. $8^{\text {th }}$ edition. The Dryden Press.

Endri. 2009. Prediksi Kebangkrutan Bank Untuk Menghadapi dan Mengelola Perubahan Lingkungan Bisnis: Analisis Model Altman Z-Score. Perbanas Quarterly Review, Vol. 2 number 1. March 2009.

Foster, G. 1986. Financial Statement Analysis. New Jersey: Prentice Hall, Englewood Cliffs.

Halim, A. and Mamduh M. H. (2009). Analisis Laporan Keuangan. $4^{\text {th }}$ edition. UPP STIM YKPN. Yogyakarta

Harahap, S. S. 2008. Analisis Kritis Atas Laporan Keuangan. Jakarta: PT. Raja Grafindo Persada. 
The Comparative Analysis of Altman Z-Score, Springate, Zmijewski, And Internal Growth Rate Model in Predicting the Financial Distress (Empirical Study on Mining Companies Listed on Indonesia Stock Exchange 2014-2017)

(Sri Mulyati and Syahrul Ilyasa)

Ikatan Akuntan Indonesia (IAI). 2009. Pernyataan Standar Akuntansi Keuangan (PSAK) No. 1: Laporan Keuangan. Jakarta: Salemba Empat.

Kasmir. 2013. Analisis Laporan Keuangan. Jakarta: Rajawali Pers.

Munawir. 2010. Analisa Laporan Keuangan. Yogyakarta: Liberty.

Peter and Yoseph, 2011. Analisis Kebangkrutan Dengan Metode Z-Score Altman, Springate dan Zwijeski pada PT. Indofood Sukses Makmur Tbk Periode 20052009. Akurat Jurnal IImiah Akuntansi, 2 (04).

Prayogo, F. 2003. Analisis Perhitungan Internal Growth Rate dan Sustainblen Growth Rate dalam menentukan kebangkrutan Perusahaan. Skripsi: Fakultas Ekonomi Universitas Kristen Petra Surabaya.

Pujiastuti, T. dan Yuharningsih. 2014. Anteseden Profitabilitas Financial Distress Pada Perusahaan manufaktur Di Indonesia. Jurnal Keuangan dan Perbankan, Vol 18, Number 1, January 2014, p. 1-13.

Ross, S. A., et al. 2009. Fundamental of Corporate Finance (translated by: Ali Akbar Yulianto). Jakarta: Salemba Empat.

Springate, Gordon L.V. 1978. Predicting the Possibility of Failure in Canadian Project. Journal Simon Fraser University.

Sugiyono. 2005. Metode Penelitian Bisnis. Bandung: Alfabeta.

Zmijewski, M. 1984. Methodological Issues Related to the Estimation of Financial Distress Prediction Models. Journal of Accounting Research. Supplement, 22, 59-82.

https://investasi.kontan.co.id/news/sektor-tambang-melonjak-25-tak-semuasaham-sektor-ini-mentereng accessed on 12 September at 14.23

https://finance.detik.com/bursa-dan-valas/d-3695726/saham-berau-duluprimadona-sekarang-ditendang-dari-bursa accessed on 12 September at $\underline{17.25}$ 